\title{
Antigenic Population Changes of Leptospira biflexa Strains Grown Under the Selective Pressure of Factorial Antibodies
}

\author{
By B. CACCIAPUOTI,* A. PINTO AND I. SIlVA \\ Centro Nazionale per le Leptospirosi, Istituto Superiore di Sanità, Roma 00161, Italy
}

(Received 15 May 1984; revised 7 September 1984)

\begin{abstract}
Serovars jequitaia and tororò of Leptospira biflexa were cultured in the presence of homologous factor serum containing factorial antibodies (FcAbs) to their major antigens. After 39 serial passages they were then re-tested to determine whether their major antigens had remained unchanged. It was found that each parent strain had been replaced by an antigenic variant. The disappearance of each parent strain and its replacement by an antigenic variant was attributed to the selective conditions imposed by FcAbs. The antigenic variants behaved like true mutants. They lacked the major serovar antigens of the parent strains and had acquired some major antigens similar to those of two different serovars, one of which belonged to the same serogroup as the parent strain and the other to a different serogroup.

A comparison of the major antigens of the parent strains with those of their antigenic variants indicated that factorial antibodies may be used selectively to obtain antigenic variants with a predefined pattern of major antigens.
\end{abstract}

\section{INTRODUCTION}

Leptospira interrogans and Leptospira biflexa, pathogenic and saprophytic species, respectivèly, are characterized by surface antigens which allow an infra-subspecific classification. Strains which cross-agglutinate at high titre with one another's antisera (prepared in rabbits), have been regarded as belonging to the same serogroup (Turner, 1968). Strains within a serogroup have been further distinguished one from another into serovars, by cross-agglutinin absorption studies in pairs (Kmety et al., 1970).

An alternative, confirmatory, approach to the classification of leptospires into serogroups and serovars was given by the identification of 'major and minor antigens' of leptospires by 'factor sera' prepared by the absorption of rabbit immune sera with clearly related serovars within the same serogroup so that the factor sera react only with specified major antigens, and sometimes with minor antigens (Kmety, 1966).

Antigenic studies of serogroups revealed typical arrangements of major and minor antigens for each serovar studied (Kmety, 1967). The advantage of such a system is that it allows each leptospiral serovar to be characterized on a qualitative basis by its set of 'major' and 'minor' antigens that can be determined by factor sera.

Variations in the antigenic pattern of leptospires are well documented. Antigenic variants were selected by growing leptospiral serovars in vitro in the presence of homologous and heterologous antisera in which polyclonal antibodies (PcAbs) against a given pattern of leptospiral antigens were represented (Bessemans et al., 1943; Bessemans \& Deram, 1947; Pike \& Schultze, 1958; Parnas et al., 1961; Kmety \& Bakoss, 1964; Ananyin \& Semynova, 1966; Bakoss, 1966; Lataste-Dorolle \& Plesko, 1969; Babudieri, 1971). These variants differed antigenically from the naturally occurring serovars.

\footnotetext{
Abbreviations: FcAbs, factorial antibodies; NSM, normal serum medium; FSM, factor serum medium; MAT, microagglutination test; McAbs, monoclonal antibodies; PcAbs, polyclonal antibodies.
} 
By the same technique, Yanagawa \& Takashima (1974) selected an antigenic variant of serovar hebdomadis that corresponded to the naturally occurring serovar kremastos of the same serogroup. This result afforded proof of the mutational origin of leptospiral serovars one from another. In the same way, Petrov \& Cernuckha (1977) isolated several antigenic variants from cultures of pomona and monjakov serovars of the Pomona serogroup, some of which belonged to the original serogroup and others to serogroup Cynopteri, thus observing the first in vitro intergroup antigenic variation of leptospires. The variant strains that belonged to serogroup Cynopteri emerged after contact of the parent strain with homologous PcAbs for a longer time than that required for the selection of variants within the original serogroup. This result was interpreted as proof that the antigenic variants that emerge under the selective pressure of PcAbs do so step by step one from another. More recently, Yanagawa \& Adachi (1978) isolated antigenic variants in vivo from experimentally infected mice, which suggests that new leptospiral serovars may emerge as a result of the immune reaction of the host to the injected strain.

In the present study, factor sera corresponding to major antigens of jequitaia and tororò serovars were prepared according to the technique of Kmety (1967). The two strains Jequitaia and Tororo were then grown in fluid medium (Babudieri, 1961) containing the corresponding homologous factor serum. The experiments were done to determine: (i) the antigenic changes that take place when strains of $L$. biflexa, under conditions of limited growth of the parent cells, are subjected to the selective pressure of homologous factor sera; (ii) the antigenic pattern of the emerging variant strains.

\section{METHODS}

Leptospiral strains. Strains of L. biflexa, the free-living, non-pathogenic species, were chosen for the present study. Type strains Bulgaria 6, Fons, Canela and Jequitaia of the Pulpudeva serogroup, and Tororò of the Tororò serogroup (Silva, 1974) were used. These strains were obtained from the National Collection of Leptospira strains kept at the National Centre for Leptospirosis in Italy (Babudieri, 1972).

Normal serum medium (NSM). Korthoff's base (1932), modified by Babudieri (1961) containing normal rabbit serum to a final concentration of $3 \%(\mathrm{v} / \mathrm{v})$, was used as a fluid culture medium.

Hyperimmune rabbit antisera (PcAbs). Three rabbits were immunized against each leptospiral strain by three intravenous injections of live leptospires on days 1, 5 and 10. Each dose consisted of $4 \mathrm{ml}$ of a well-grown culture of leptospires in NSM, centrifuged and resuspended in Korthoffs base.

Immune sera were obtained by bleeding the rabbits $10 \mathrm{~d}$ after the last injection. Those with titres of 6400-51 200 against live leptospires of the homologous strain when tested by the microscopic agglutination test (MAT) were considered adequate. The three rabbit antisera, with titres in the above mentioned range, were pooled to provide the PcAbs specific to the strain injected.

Microscopic agglutination of live leptospires test (MAT). This was used to titrate PcAbs and factor sera (Turner, 1968). Briefly, $100 \mu \mathrm{l}$ of a series of doubling dilutions of immune serum starting with a dilution of 1 in 50 was mixed with the same volume of leptospiral culture. The reaction mixtures were incubated at $37^{\circ} \mathrm{C}$ in a water-bath for $90 \mathrm{~min}$. The test was read under a dark-field microscope at a magnification of $100 \times$ and the end point was defined as the highest dilution of serum that agglutinated $50 \%$ or more of the cells.

Cross-absorption of agglutinins. Cross-absorption of agglutinins in PcAbs by heterologous leptospira serovars was done by the method of Kmety et al. (1970). Briefly, each immune serum was absorbed with a suspension of heterologous serovar or serovars. A well-grown leptospira culture was concentrated by high-speed centrifugation $(15000 \mathrm{~g})$ for $30 \mathrm{~min}$ and the deposit was resuspended to a density $40-80$ times that of the original culture. This dense suspension $(9.6 \mathrm{ml})$ was added to antiserum $(0.4 \mathrm{ml})$, a little at a time during $30 \mathrm{~min}$. After a $3 \mathrm{~h}$ absorption period at $32^{\circ} \mathrm{C}$, the leptospires in the reaction mixture were sedimented again by centrifugation. The supernatant diluted 1 in 25 constituted the absorbed serum. This was tested by MAT against the absorbing strain(s) to ensure that the removal of corresponding antibodies was sufficient (a residual titre of 100-200 was allowed).

Factor sera. Factor sera were prepared according to the method of Kmety $(1960 a, b)$ by cross-absorption of Jequitaia and Tororo antisera with Canela and Jequitaia strains, respectively. Titrations of Jequitaia and Tororò factor sera demonstrated high-titre factorial antibodies (FcAbs, antibody titres $\geqslant 1600$ ) to one or more major antigens of the homologous strain. In addition FcAbs to minor antigens (antibody titres less than 1600) of some heterologous strains were represented in both factor sera (Table 1). The results of the absorption tests were confirmed by repeating the tests two or more times and the average titre was taken in those cases where there were differences.

It must be emphasized that FcAbs in factor sera are not the same as monoclonal antibodies (McAbs); in fact each $\mathrm{FcAb}$ includes a number of different McAbs, each one specific to a major or minor leptospira antigen; 
Table 1. FcAbs in factor sera of Jequitaia and Tororò strains

\begin{tabular}{|c|c|c|c|c|c|c|}
\hline \multirow[b]{2}{*}{ Immune serum } & \multirow{2}{*}{$\begin{array}{l}\text { Absorbing } \\
\text { strain }\end{array}$} & \multicolumn{5}{|c|}{ Cross-agglutination titres* } \\
\hline & & Bulgaria 6 & Fons & Canela & Jequitaia & Tororò \\
\hline Jequitaia & Unabsorbed & 3200 & 1600 & 6400 & 6400 & 200 \\
\hline $\begin{array}{l}\text { Jequitaia factor } \\
\text { serum }\end{array}$ & Canela & 800 & - & - & 1600 & - \\
\hline Tororò & Unabsorbed & 3200 & 800 & 6400 & 1600 & 12800 \\
\hline $\begin{array}{l}\text { Tororò factor } \\
\text { serum }\end{array}$ & Jequitaia & 800 & 400 & 400 & - & 6400 \\
\hline
\end{tabular}

- , Negative (titre $<100$ ).

* Reciprocal of the highest dilution of serum that results in $50 \%$ microagglutination. Values given are the means of at least two tests. Post-absorption titres equal to or more than 1600 correspond to one or more major antigens of each serovar.

moreover each factor serum may contain several FcAbs owing to the singularity of the antigenic mosaic of each leptospira serovar. The multiplicity of FcAbs in each factor serum allows it to act as a highly selective tool when confronted with the antigenic mosaic of a given leptospira serovar, provided that the FcAbs against major antigens common to other serovars within the same serogroup have been absorbed out.

Factor serum medium (FSM). This consisted of NSM to which was added a factor serum to a final concentration of approx. 15 agglutinating units (a.u.) $\mathrm{ml}^{-1}$. The number of a.u. present in the FSM prepared with each factor serum was calculated by dividing the titre of the factor serum to the homologous strain by the final dilution of the factor serum in the culture medium. For example Tororò factor serum with a titre of 1600 against the homologous strain (Table 1) was diluted 1 in 25 during the cross-absorption procedure and so it contained 1600/25= 64 a.u. $\mathrm{ml}^{-1}$. By adding one volume of factor serum to three volumes of normal serum medium, a FSM containing $64 / 4=16$ a.u. $\mathrm{ml}^{-1}$ was obtained.

Serial transfers of strains. Throughout the course of the study, each strain was cultured both in NSM and FSM at $32{ }^{\circ} \mathrm{C}$. Subcultures were made every $10 \mathrm{~d}$ by inoculating $0.3 \mathrm{ml}$ of each culture into tubes containing $5 \mathrm{ml}$ of the same medium ( 39 times in all before being tested for antigenic variants).

\section{RESULTS}

After 39 serial passages in NSM and FSM, strains Jequitaia and Tororò were retested against their homologous factor sera.

No antigenic changes were observed in the major antigens in the strains grown in NSM. However, in the strains grown in FSM, a total population change was observed, the parent strain in each case having been replaced by an antigenic variant. Both strains grown in the homologous FSM lost their corresponding major antigens. An eightfold decrease in titre to factor serum Jequitaia was observed in strain Jequitaia (from 1600 to 200 in MAT); and a 64-fold decrease in titre to factor serum Tororò was observed in strain Tororò (from 6400 to $<100$ in MAT) (Table 2). Moreover, both variant strains cross-reacted with the heterologous factor serum (titre of 400 in MAT) demonstrating minor antigens not present in the original strain (Table 2).

The altered strains were tested by cross-absorption of agglutinins in pairs with strains of Pulpudeva and Tororò serogroups for the presence of new surface antigens. Each series of crossabsorption tests was performed twice. If there were differences in titre between the two experiments, in some cases a difference of one titration step, then the lower value was reported.

The jequitaia variant exhibited the major antigens of the canela serovar within the same Pulpudeva serogroup, although the canela serovar appeared to have one more major antigen which was lacking in the jequitaia variant, as demonstrated by cross-absorption tests between canela immune serum and the jequitaia variant (Table 3 ).

The tororò variant was shown to be an inter-serogroup variant from the Tororò to Pulpudeva serogroup, since it exhibited all the major antigens of the jequitaia serovar, as demonstrated by cross-absorption tests between jequitaia immune serum and the tororò variant (Table 3 ). Thus it appeared that the major antigens in the variant strains corresponded to those in the serovars used as absorbing strains in the preparation of factor sera against the parent strain (Table 1). 
Table 2. Antigenic losses in strains grown in homologous factor sera

$\begin{array}{lcccc}\text { Factor serum } & \overbrace{\text { NSM }}^{\text {Jequitaia grown in: }} & \text { FSM } & \overbrace{\mathrm{NSM}}^{\text {Tororò grown in: }} & \text { FSM } \\ \text { Jequitaia (abs. Canela) } & 1600 & 200 & - & 400 \\ \text { Tororò (abs. Jequitaia) } & - & 400 & 6400 & -\end{array}$

- , Negative (titre $<100$ ).

* Reciprocal of the highest dilution of serum that results in $50 \%$ microagglutination.

Table 3. Relationships between antigenic variants and strains in Pulpudeva and Tororò serogroups

\begin{tabular}{|c|c|c|c|c|c|c|c|c|}
\hline \multirow[b]{2}{*}{$\begin{array}{l}\text { Immune } \\
\text { serum }\end{array}$} & \multirow[b]{2}{*}{$\begin{array}{l}\text { Absorbing } \\
\text { strain }\end{array}$} & \multicolumn{7}{|c|}{ Cross-agglutination titres* } \\
\hline & & Bulgaria 6 & Fons & Canela & Jequitaia & Tororò & $\begin{array}{l}\text { Jequitaia } \\
\text { variant }\end{array}$ & $\begin{array}{l}\text { Tororò } \\
\text { variant }\end{array}$ \\
\hline $\begin{array}{c}\text { Jequitaia } \\
\text { variant }\end{array}$ & $\begin{array}{l}\text { Unabsorbed } \\
\text { Canela }\end{array}$ & $\begin{array}{l}6400 \\
-\end{array}$ & $\begin{array}{c}6400 \\
-\end{array}$ & $\begin{array}{r}25600 \\
800\end{array}$ & $\begin{array}{r}12800 \\
400\end{array}$ & $\begin{array}{l}800 \\
-\end{array}$ & $\begin{array}{r}25600 \\
200\end{array}$ & $\begin{array}{r}6400 \\
100\end{array}$ \\
\hline Canela & $\begin{array}{l}\text { Unabsorbed } \\
\text { Jequitaia } \\
\text { variant }\end{array}$ & $\begin{array}{l}3200 \\
-\end{array}$ & $\begin{array}{c}6400 \\
-\end{array}$ & $\begin{array}{r}25600 \\
1600\end{array}$ & $\begin{array}{c}12800 \\
-\end{array}$ & $\begin{array}{c}1600 \\
-\end{array}$ & $\begin{array}{c}25600 \\
-\end{array}$ & $\begin{array}{r}6400 \\
100\end{array}$ \\
\hline $\begin{array}{l}\text { Tororò } \\
\text { variant }\end{array}$ & $\begin{array}{l}\text { Unabsorbed } \\
\text { Jequitaia }\end{array}$ & $\frac{12800}{-}$ & $\frac{6400}{-}$ & $\begin{array}{r}25600 \\
400\end{array}$ & $\begin{array}{r}6400 \\
200\end{array}$ & $\begin{array}{l}400 \\
-\end{array}$ & $\frac{12800}{-}$ & $\begin{array}{r}6400 \\
100\end{array}$ \\
\hline Jequitaia & $\begin{array}{l}\text { Unabsorbed } \\
\text { Tororò } \\
\text { variant }\end{array}$ & $\begin{array}{l}1600 \\
-\end{array}$ & $\begin{array}{c}1600 \\
-\end{array}$ & $\begin{array}{r}6400 \\
400\end{array}$ & $\begin{array}{r}6400 \\
100\end{array}$ & $\begin{array}{l}200 \\
-\end{array}$ & $\begin{array}{c}12800 \\
-\end{array}$ & $\begin{array}{c}6400 \\
-\end{array}$ \\
\hline
\end{tabular}

Both variant strains, replacing the parental strains in FSM, were then transferred to NSM where 30 or more serial passages were performed at intervals of $10 \mathrm{~d}$. After that, both strains were retested by agglutinin cross-absorption tests in pairs. The antigenic patterns of both variant strains did not revert to those of the original serovars but remained the same as those observed after the first 39 serial passages in FSM (Table 3).

\section{DISCUSSION}

Serovars jequitaia and tororò of Leptospira biflexa species, grown in the presence of homologous factor sera, underwent a total population change. Each parent strain was replaced by an antigenic variant. This phenomenon was clearly related to the relative selective conditions imposed by the homologous factor serum in which each parent strain was grown.

A first question posed by these results is whether the antigenic variants are phenotypic or genotypic ones. Not all population changes in bacteria involve mutation and selection. Modification, i.e. temporary, non-heritable phenotypic changes can occur under the influence of environmental agents. Such modifications affect all the cells of a single genotype after transfer to different environmental conditions. These modified characteristics are maintained as long as the cells are kept under those particular conditions. Sometimes the altered phenotype may even be maintained for short periods after the return of the cells to the original environment, an effect that may involve intracellular storage of intermediate products.

On the contrary, the antigenic patterns of both variant strains acquired in this investigation did not revert to those of the original serovars, even after 30 serial passages in NSM performed at intervals of $10 \mathrm{~d}$, which correspond to about 360 generations of leptospires based on a generation time of approximately $20 \mathrm{~h}$. In consequence the antigenic variants behaved like true 
serovars which are stable and maintain their antigenic patterns under conditions that are not selective for their maintenance. The conclusion may be drawn that both jequitaia and tororo variants are genotypic variants with stable inheritable antigenic patterns like those of true serovars, emerging under the selective pressure of homologous factor sera on parent strains.

The second question posed is why each parental strain was replaced by the emerging antigenic mutant. The phenomenon cannot be attributed to the relatively selective conditions due to the $\mathrm{FcAb}$ present in the culture medium. In fact, FSM fails by itself to suppress the growth of the parent cells entirely, but provides an opportunity for the establishment of antigenic mutants with greater selective value under the prevailing conditions. We can only affirm that under conditions of limited growth of the parent cells, the selective growth and survival of mutants especially fitted to survive under the existing environmental conditions becomes a major factor in population changes.

The same phenomenon has been described in mixed cultures of leptospira serovars, where only one serovar is likely to survive six to ten serial passages in NSM, even if this medium does not seem to be selective for any one of the strains in culture. (Addamiano \& Babudieri, 1955; Pike \& Schultze, 1958; Yu-En Shu et al., 1965; Babudieri, 1968; Magliocchetti-Lombi \& Babudieri, 1968).

On the basis of the above results, a double role appears to be played by factor sera in selecting antigenic mutants of leptospires with a given pattern of surface antigens.

First, the homologous FcAb to the parent strain grown in FSM selected mutants which lacked their corresponding major antigens. A further role concerns the emerging antigens of the selected mutant. This role was supported by the absorbing strain(s) used to prepare the factor serum. Taking into account the fact that the absorbing strain removes from each immune serum all the antibodies that correspond to its own surface antigens, the hypothesis may be made that this opens the way to mutants with antigens corresponding to those of the absorbing strain, as was the case in both our experiments.

Factor sera, with a given pattern of factorial antibodies, may therefore be used as selective tools to obtain antigenic mutants of a leptospira strain at inter-serovar and inter-serogroup levels, with a predefined pattern of major antigens.

The authors are greatly indebted to Dr Joyce D. Coghlan, former Director of the PHLS Leptospira Reference Laboratory, London, for her careful review of the manuscript. Thanks are due to Dr Duncan E. Stewart-Tull, Department of Microbiology, University of Glasgow, for his helpful comments on the text.

\section{REFERENCES}

AdDAmiano, L. \& Babudieri, B. (1955). Ricerche sul comportamento di colture associate di leptospire. Rendiconti dell' Istituto superiore di sanità 18, 270-279.

ANANYIN, V. V. \& SEMYNova, L. P. (1966). Variability of the serological and antigenic properties of pathogenic leptospires in experimental conditions. Journal of Microbiology, Epidemiology and Immuno$\log y$ 3, 34-39.

BABUDIERI, B. (1961). Laboratory diagnosis of leptospirosis. Bulletin of the World Health Organization 24, 45-58.

BABUDIERI, B. (1968). A new technique for the purification of newly isolated leptospira strains. Bulletin of the World Health Organization 39, 939940.

BABUDIERI, B. (1971). Isolation and study of antigenic mutants of saprophytic and pathogenic leptospires. Zentralblatt für Bakteriologie, Mikrobiologie und Hygiene (Abteilung I, Originale A) 218, 75-86.

BABUDIERI, B. (1972). List of Leptospira strains kept in the WHO-FAO Leptospira reference laboratory in Rome. Annali dell' Istituto superiore di sanità 8, 159 196.
BAKoss, P. (1966). Contribution à la variabilité de la structure antigènique des leptospires. Annales de la Société belge de médicine tropicale 46, 97-100.

Bessemans, A. \& Deram, R. (1947). Nouvelle transformation antigènique d'une souche leptospirienne. Bulletin de l'Académie royale de médicine Belgique 12 , 236-245.

Bessemans, A., Wittebolle, P. \& Niemegers, L. (1943). Modification expérimentale durable de la structure antigènique des leptospires. Bulletin de l'Académie royale de médicine Belgique 8, 442458.

KMETY, E. (1960a). Contribution to the antigenic structure of leptospira serotypes forming the Australis serogroup. Journal of Hygiene, Epidemiology, Microbiology and Immunology 4, 171-174.

KMETY, E. (1960b). An attempt to subdivide the Leptospira Australis A serogroup. In Leptospirae and Leptospirosis in Man and Animals. Wydaw Polskiej Akademie Nauk Warszawa 27-39.

KMETY, E. (1966). Main antigens as criterion for differentiating leptospiral serotypes. Annales de la Société belge de médicine tropicale 46, 103-108. 
KMETY, E. (1967). Faktorenanalyse von Leptospiren der Icterohaemorrhagiae und einiger werwandter Serogruppen. Biologické práce Slovenskej akademie vied 8, 3.

KMETY, E. \& BAKoss, P. (1964). Beitrag zur Variabilität der Antigenerstruktur der Leptospiren. In $I I$ International Symposium on Leptospirae and Leptospiroses in Man and Animals, pp. 123-128. Warzawa: Lublin.

Kmety, E., Galton, M. M. \& Sultzer, C. R. (1970). Further standardization of the agglutinin-absorption test in the serology of leptospirosis. Bulletin of the World Health Organization 42, 733-738.

KORTHOFF, G. (1932). Experimentelles Schlammfieber beim Menschen. Zentralblatt für Bakteriologie, Parasitenkunde, Infektionskrankheiten und Hygiene (Abteilung I, Originale) 125, 429-434.

Lataste-Dorolle, C. \& Plesko, L. (1969). Analyse factorielle des antigènes leptospiriens ('Serofacteurs de Kmety'). Bulletin de l'Institut Pasteur 67, 23232348.

Magliocchetti-Lombi, P. \& Babudieri, B. (1968). Ricerche sulle colture associate di leptospira. Annali dell'Istituto superiore di sanità 4, 291-304.

Parnas, J., Malinowski, R. \& Halgas, A. (1961). Experimentelle Forschungen über die Variabilität der Leptospiren. Zentralblatt für Bakteriologie und
Hygiene (Abteilung I, Originale A) 183, 101118.

Petrov, E. M. \& Cernuckha, Y. C. (1977). Potential variability of Leptospira serovars belonging to the same group. Zentralblatt für Bakteriologie und $\mathrm{Hy}$ giene (Abteilung I, Originale A) 239, 252-261.

Pike, R. M. \& Schultze, M. L. (1958). Serologic variants of leptospire types resulting from growth in immune serum. Journal of Immunology 81, 172-175.

Silva, I. (1974). Studio sistematico di leptospire isolate in Brasile. Annali dell'Istituto superiore di sanità 10, $21-25$.

TURNER, L. H. (1968). Leptospirosis. II. Serology. Transactions of the Royal Society of Tropical Medicine and Hygiene 62, 880-899.

YanaGaWA, R. \& ADACHI, Y. (1978). Studies of antigenic variants of leptospira isolated from experimentally infected mice. Zentralblatt für Bakteriologie und Hygiene (Abteilung I, Originale A) 240, 347-355. YanaGawa, R. \& Takashima, J. (1974). Conversion of serotype in Leptospira from hebdomadis to kremastos. Infection and Immunity 10, 1439-1442.

Yu-En-SHU, WU SHIN-YI \& LeE De-Fen (1965). Studies on the antagonism between types of leptospires and on the method of detecting infections of two mixed types of leptospira. Scientia sinica 14, 901912. 